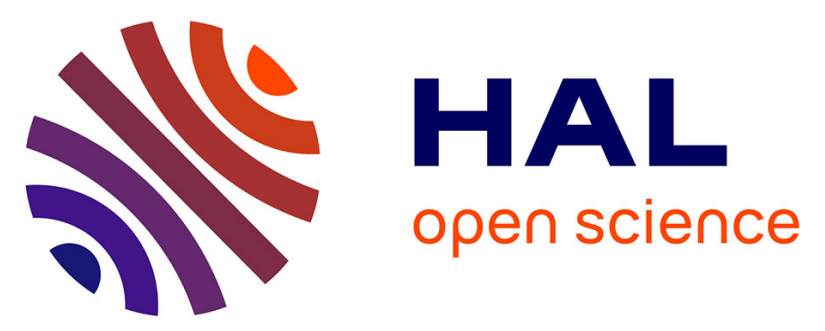

\title{
A novel non-linear model-based control strategy to improve PEMFC water management - The flatness-based approach
}

Cédric Damour, Michel Benne, Brigitte Grondin-Perez, Jean-Pierre Chabriat, Bruno G. Pollet

\section{To cite this version:}

Cédric Damour, Michel Benne, Brigitte Grondin-Perez, Jean-Pierre Chabriat, Bruno G. Pollet. A novel non-linear model-based control strategy to improve PEMFC water management - The flatness-based approach. International Journal of Hydrogen Energy, 2015, 40 (5), pp.2371-2376. 10.1016/j.ijhydene.2014.12.052 . hal-01221974

\section{HAL Id: hal-01221974 \\ https://hal.univ-reunion.fr/hal-01221974}

Submitted on 26 Oct 2016

HAL is a multi-disciplinary open access archive for the deposit and dissemination of scientific research documents, whether they are published or not. The documents may come from teaching and research institutions in France or abroad, or from public or private research centers.
L'archive ouverte pluridisciplinaire HAL, est destinée au dépôt et à la diffusion de documents scientifiques de niveau recherche, publiés ou non, émanant des établissements d'enseignement et de recherche français ou étrangers, des laboratoires publics ou privés. 


\title{
Short Communication
}

\section{A novel non-linear model-based control strategy to improve PEMFC water management - The flatness-based approach}

\author{
Cédric Damour ${ }^{a}$, Michel Benne ${ }^{a}$, Brigitte Grondin-Perez ${ }^{a}$, \\ Jean-Pierre Chabriat ${ }^{a}$, Bruno G. Pollet ${ }^{b \text {,* }}$ \\ ${ }^{a}$ LE2P EA 4079, Université de La Réunion, 97715 Saint-Denis, France \\ ${ }^{\mathrm{b}}$ HySA Systems Competence Centre, SAIAMC, The University of the Western Cape, Robert Sobukwe Road, \\ Belluille 7535, Cape Town, South Africa
}

\begin{abstract}
A B S T R A C T
In the area of PEMFC, water management and thus membrane humidity still remains one of the most challenging issues affecting PEMFC efficiency and lifetime. In this investiga-tion, an innovative method to improve PEMFC water management is presented and a non-linear model-based control strategy is proposed. The novelty of this approach relies upon a simplified PEMFC model combining the benefits of the Differential Flatness Theory. Efficiency and relevance of the proposed water management strategy is confirmed in simulation environment through several controlled scenarios. It was found that in each case, the flatness-based controller successfully regulates the membrane humidity, while avoiding flooding or even membrane drying that can lead to irreversible damage. Furthermore, the novel model demonstrates excellent performance in terms of setpoint tracking, disturbances rejection and robustness against parameters uncertainties and measurement noise. Overall, this novel approach appears to be a possible and promising towards improving PEMFC water management issues.
\end{abstract}

\section{Introduction}

Proton Exchange Membrane Fuel Cell (PEMFC) is proven to be a promising environmental friendly technology for portable, mobile and stationary applications. However, several issues still need to be addressed and solved to reduce its cost, extend its lifetime and improve its efficiency. Among them, water management still remains one of the most challenging problems. Proton Exchange Membrane (PEM) humidity strongly affects PEMFC performance and lifetime. On the one hand, excess of water can cause flooding, which lead to a cell voltage drop. On the other hand, water leaks may dry the membrane and causes irreversible damages. Therefore, to ensure optimal

\footnotetext{
* Corresponding author. Tel.: +27 (0)714840323.

E-mail address: bgpollet@hysasystems.org (B.G. Pollet).

URL: http://www.hysasystems.org
} 


\begin{tabular}{|c|c|c|c|}
\hline \multicolumn{2}{|c|}{ Nomenclature } & $\mathrm{ca}$ & cathode \\
\hline$a$ & & gen & generated \\
\hline$a^{a}$ & water activities & in & inlet \\
\hline$F$ & Faraday constant, C & $m$ & average \\
\hline I & current, A & $m b r$ & membrane \\
\hline h & orifice flow constant, $\mathrm{kg} \mathrm{s}^{-1} \mathrm{~Pa}^{-1}$ & $\mathrm{~N}_{2}$ & nitrogen \\
\hline M & molecular mass, $\mathrm{kg} \mathrm{mol}^{-1}$ & $\mathrm{O}_{2}$ & oxygen \\
\hline$n$ & number of cells & out & outlet \\
\hline$P$ & pressure, $\mathrm{Pa}$ & $\mathrm{rm}$ & return manifold \\
\hline $\begin{array}{l}\mathrm{K} \\
\mathrm{T}\end{array}$ & gas constant, J $\mathrm{Kg}-\mathrm{K}$ & sat & saturation \\
\hline $\mathrm{V}$ & volume, $\mathrm{m}^{3}$ & st & stack \\
\hline W & mass flow rate, $\mathrm{kg} \mathrm{s}^{-1}$ & $v$ & vapor \\
\hline \multirow{2}{*}{\multicolumn{2}{|c|}{ Greek letters }} & \multicolumn{2}{|c|}{ Controller parameters } \\
\hline & membrane water content & $k_{i, j}$ & controller tuning parameters \\
\hline$\phi$ & relative humidity, $\%$ & $u$ & input vector \\
\hline (1) & humidity ratio & $x$ & state vector \\
\hline & & $\mathrm{y}$ & output vector \\
\hline \multicolumn{2}{|c|}{ Subscripts } & $y_{r e f}$ & set-point output vector \\
\hline$a$ & air & $\psi(\cdot)$ & $(\cdot), \varphi_{2}(\cdot)$ mapping functions \\
\hline
\end{tabular}

efficiency while avoiding flooding or membrane drying, the PEM has to be properly hydrated.

Many studies have been conducted to elucidate water transport phenomena in PEMFCs. In addition, to improve the understanding of these phenomena, while avoiding additional costs related to experimental studies, numerous models have been developed. A fairly recent and very detailed review on experimental studies and modeling works related to water transport in PEMFC can be consulted in Ref. [1].

However, whereas numerous studies have focused on water transport modeling in PEMFC, a very few studies have been reported in the control of the membrane humidity. Among them, Haddad et al. 2008 [2] proposed an open-loop control of the membrane humidity using the water mole fractions in the inlet gases as manipulated variables. Simulation results showed that an appropriate control of the membrane water content could minimize the electrical energy loss. Zhang et al. 2008 [3] designed a model-based predictive controller to maintain an appropriate water concentration in the cathode, as long as the manipulated variable is the mass flow rate of injected water from humidifier. The proposed controller, tested in simulated environment, allowed the reduction of water concentration fluctuation in the cathode. Hussaini and Wang 2010 [4] proposed a water management strategy based on an intermittent external humidification protocol. This approach, dedicated to low temperature fuel cells operating at constant current densities, aimed to maintain the membrane close to full humidification, while avoiding flow field plate channel flooding. Experimental results showed that appropriate control of dry and humid flows durations improved the fuel cell performance. Sedighzade and Fathian 2011 [5] proposed to manipulate the anode and cathode water mole fractions in views of maintaining a constant voltage and keeping the membrane humidity within an appropriate range, regardless of the cell current. In this investigation, the authors designed a recurrent neural network controller. Simulation results, performed for a single cell PEMFC, showed that the controller was able to track the voltage set-point, while keeping the membrane water content within its standard limits. Khoeiniha and Zarabadipour 2012 [6] proposed an optimal PID controller based on genetic algorithm to improve water management in PEMFC. Herein, the anode and cathode water mole fractions were manipulated to regulate the output cell voltage and maintain the cell water content within an acceptable interval. The controller, implemented in simulation environment, exhibited satisfactory cell voltage tracking capability, while keeping the water content within an appropriate range.

In this paper, a flatness-based approach model is proposed in views of tackling PEMFC water management issues. To ensure optimal PEMFC efficiency, while avoiding flooding or membrane drying, a flatness-based controller is designed to regulate the membrane humidity. By using the Differential Flatness Theory, the control law is explicitly expressed in terms of the so-called flat outputs and a finite number of their derivatives, without integrating any differential equations. In this manner, the controller takes into account the non-linear process behaviors, while avoiding hefty computational exercise. This paper is organized as follows: PEMFC water management design is dedicated to the flatness-based controller design; in Simulation-based results, the performance of the proposed controller in terms of tracking capability, disturbances rejection ability, robustness against parameter uncertainties and measurement noise, is investigated in simulation environment.

\section{PEMFC water management design}

Differential Flatness Theory has been proven to be a very powerful concept, which has been successfully applied to a variety of non-linear systems across various Engineering disciplines ranging from chemical reactor to space robotic [7-16]. Recently, a few works emphasizing benefits of flatness-based controller regarding PEMFC control have been reported $[12,17,18]$. 


\section{Differential Flatness Theory principle}

Given a non-linear system such as:

$\dot{x}=f(x, u) ; x \in \mathbb{R}^{n} ; u \in \mathbb{R}^{m}$

where $x=\left[x_{1}, x_{2}, \ldots, x_{n}\right]^{T}$ and $u=\left[u_{1}, u_{2}, \ldots, u_{m}\right]^{T}$ denote state and input vectors, respectively.

This system is differentially flat, or flat, if and only if, there exists an output vector $y \in \mathbb{R}^{m}$ called flat output, such as $y=\left[y_{1}, y_{2}, \ldots, y_{m}\right]^{T}=\psi\left(x, \dot{u}, \ldots, u^{(\beta)}\right)$ implies [19-21]:

$\left\{\begin{array}{l}x=\varphi_{1}\left(y, \dot{y}, \ldots, y^{(\alpha)}\right) \\ u=\varphi_{2}\left(y, \dot{y}, \ldots, y^{(\alpha+1)}\right)\end{array}\right.$

$\alpha$ and $\beta$ are finite numbers of derivatives, $\psi: \mathbb{R}^{n} \times\left(\mathbb{R}^{m}\right)^{(\beta+1)}$, $\varphi_{1}:\left(\mathbb{R}^{m}\right)^{\alpha} \times \mathbb{R}^{n}$ and $\varphi_{2}:\left(\mathbb{R}^{m}\right)^{(\alpha+1)} \times \mathbb{R}^{m}$.

Let us recall that a flat system is equivalent to a linear one via an endogenous feedback [19-21]. Therefore, if the above non-linear system is flat, one can find an endogenous feedback such as: $y_{i}^{(\alpha+1)}=v_{i}$. In this context, the tracking control problem can be written as:

$v_{i}=y_{\text {ref, } i}^{(\alpha+1)}+\sum_{j=0}^{\alpha} \mathrm{k}_{\mathrm{i}, \mathrm{j}} \mathrm{e}_{\mathrm{i}}^{(\mathrm{j})} \quad \mathrm{i}=1, \ldots, \mathrm{m}$

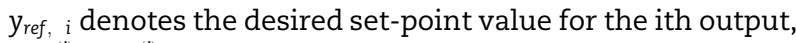
$\mathrm{e}_{\mathrm{i}}^{(\mathrm{j})}=\mathrm{y}_{\text {ref,i }}^{(j)}-\mathrm{y}_{\mathrm{i}}^{(j)}$ is the tracking error, and parameters $k_{i, j}$ are chosen such that the $m$ polynomials $\left[s^{(\alpha+1)}+\sum_{j=0}^{\alpha} k_{i, j} s^{(j)}\right]$ are strictly Hurwitz.

Note that this definition allows expressing all systems' variables and control actions, in terms of flat outputs and a finite number of their derivatives. Flatness-based controllers offer a great trade-off between not optimal linear controllers, such as proportional integral derivative controllers, and high computational cost non-linear controllers such as non-linear model-based predictive control strategies. Indeed, flatnessbased controllers take account of the non-linear behavior of the process while avoiding heavy computations.

\section{Flatness-based controller design}

In this work, a flatness-based controller was designed to control the membrane humidity based upon the following simplified model:

$\frac{d m_{w, c a}}{d t}=W_{v, c a, \text { in }}-W_{v, c a, o u t}+W_{v, c a, g e n}+W_{v, m b r}$

where $\mathrm{W}_{v, \text { mbr }}$ denotes the mass flow rate of water across the membrane, and the inlet mass flow rate of vapor $\mathrm{W}_{v, c a, \text { in }}=\mathrm{W}_{c a, \text { in }}\left(1-1 /\left(1+\omega_{c a, i n}\right)\right)$ is written as a function of the inlet mass flow rate $W_{c a, i n}$ and the humidity ratio $\omega_{c a, i n}$ :

$\omega_{\text {ca,in }}=\frac{M_{v} \phi_{c a, i n} P_{\text {sat }}^{T_{c a, i}}}{\left(\left(P_{c a, i n}-\phi_{c a, i n} P_{\text {sat }}^{T_{\text {cain }}}\right) M_{a}\right)}$
$M_{v}$ is the vapor molar mass, the air molar mass $M_{a}=\mathscr{Y}_{\mathrm{O}_{2}} M_{\mathrm{O}_{2}}+\left(1-\mathscr{Y}_{\mathrm{O}_{2}}\right) M_{\mathrm{N}_{2}}$ depends on the fraction of oxygen in the dry air $\mathscr{Y}_{\mathrm{O}_{2}}$, the molar mass of oxygen $\mathrm{M}_{\mathrm{O}_{2}}$, and nitrogen, $M_{\mathrm{N}_{2}}$. The vapor saturation pressure $P_{\text {sat }}^{T_{\text {cain }}}$ is obtained from the equation given in Ref. [22]. $\phi_{c a, i n}$ and $P_{c a, \text { in }}$ are the relative humidity and pressure of the inlet gas at the cathode, respectively.

The outlet mass flow rate of vapor $\mathrm{W}_{v, \text { ca,out }}=\mathrm{W}_{\text {ca,out }}\left(1-1 /\left(1+\omega_{\text {ca,out }}\right)\right)$ depends on the outlet mass flow rate $W_{c a, o u t}$ and the humidity ratio $\omega_{c a, o u t}$ :

$\mathrm{W}_{\text {ca,out }}=\mathscr{K}_{c a}\left(\mathrm{P}_{c a}-\mathrm{P}_{\mathrm{rm}}\right)$

$\omega_{\text {ca }, \text { out }}=\frac{M_{v} P_{v, c a}}{\left(\left(P_{\mathrm{O}_{2}}+P_{N_{2}}\right) M_{a}\right)}$

$\mathscr{K}_{c a}$ is the orifice flow constant, $P_{c a}=P_{\mathrm{O}_{2}}+P_{\mathrm{N}_{2}}+P_{v, c a}$ the cathode total pressure and $P_{r m}$ the return manifold pressure. The partial pressure of oxygen, nitrogen and vapor are obtained according to the ideal gas law such as $P_{\mathrm{O}_{2}}=\left(m_{\mathrm{O}_{2}} R_{\mathrm{O}_{2}} T_{\text {st }}\right) / \mathrm{V}_{\text {ca }}, \quad P_{\mathrm{N}_{2}}=\left(m_{\mathrm{N}_{2}} R_{\mathrm{N}_{2}} \mathrm{~T}_{\mathrm{st}}\right) / \mathrm{V}_{c a} \quad$ and $P_{v, c a}=\left(m_{v, c a} R_{v} T_{s t}\right) / V_{c a}$. The mass flow rate of generated water $W_{v, \text { ca,gen }}=M_{v} n I_{s t} / 2 F$ is a function of the stack current $I_{s t}$, the number of cells $n$, and the Faraday constant $F$.

Considering $x=m_{w, c a}$ as state variable, $u=W_{c a, i n}$ as manipulated variable and $y=m_{w, c a}$ as output, it is obvious that $x=\varphi_{1}(y)$. Besides, from Eq. (4) the control variable can be expressed in terms of the output $y$ and its first time derivative:

$$
\begin{gathered}
u=\frac{\left[\dot{y}+\mathscr{K}_{c a}\left(P_{\mathrm{O}_{2}}+P_{\mathrm{N}_{2}}+\frac{y R_{v} T_{s t}}{V_{c a}}-P_{r m}\right)\left(1-\frac{\left(\left(P_{\mathrm{O}_{2}}+P_{\mathrm{N}_{2}}\right) \mathrm{M}_{a} \mathrm{~V}_{c a}\right)}{{ } \mathrm{M}_{v} R_{v} \mathrm{~T}_{\mathrm{st}}}\right)\right]}{\left(1-1 /\left(1+\omega_{c a, \text { in }}\right)\right)} \ldots \\
+\frac{-\mathrm{W}_{v, \text { ca,gen }}-\mathrm{W}_{v, \text { mbr }}}{\left(1-1 /\left(1+\omega_{c a, \text { in }}\right)\right)}=\varphi_{2}(\mathrm{y}, \dot{\mathrm{y}})
\end{gathered}
$$

Since $x=\varphi_{1}(y)$ and $u=\varphi_{2}(y, y)$ and according to Eq. (2), the system Eq. (4) is differentially flat and has y as flat output. Once the system has been proven to be flat, the tracking control problem becomes straightforward, and the closedloop control law, deduced from Eq. (3) and Eq. (4), is given by:

$u=\operatorname{Sat}_{u_{\min }}^{u_{\max }}\left(\frac{\mathrm{y}_{\text {ref }}^{(1)}+\mathrm{k}_{1}\left(\mathrm{y}_{\text {ref }}-\mathrm{y}\right)+\mathrm{W}_{v, \mathrm{ca}, \text { out }}-\mathrm{W}_{v, \text { ca,gen }}-\mathrm{W}_{v, \text { mbr }}}{\left(1-1 /\left(1+\omega_{\mathrm{ca}, \mathrm{in}}\right)\right)}\right)$

where $y_{\text {ref }}=m_{\text {ref, w,ca }}$ denotes the desired mass of water, and Sat $: \mathbb{R} \rightarrow \mathbb{R}$ denotes a saturation map, such as:

$\operatorname{Sat}_{u_{\min }}^{u_{\max }}(u)=\left\{\begin{array}{cc}u_{\text {min }} & \text { if } u \leq u_{\text {min }} \\ u_{\text {max }} & \text { if } u \geq u_{\text {max }} \\ u & \text { otherwise }\end{array}\right.$

Note that the saturation constraints on the manipulated variable are used to ensure safety operation of the PEMFC system.

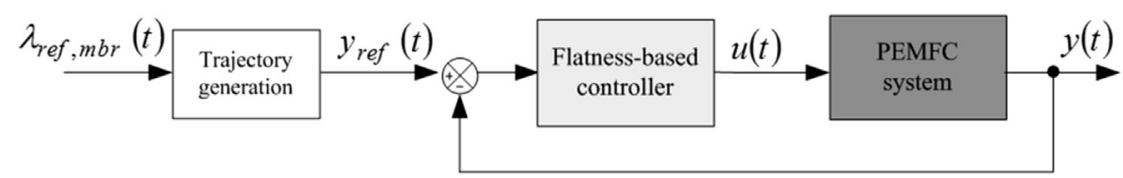

Fig. 1 - Overall control scheme. 


\begin{tabular}{|c|c|c|}
\hline Symbols & Variables & Values \\
\hline $\mathrm{M}_{\mathrm{O}_{2}}$ & Air molar mass & $32 \times 10^{-3} \mathrm{~kg} \mathrm{~mol}^{-1}$ \\
\hline $\mathrm{M}_{\mathrm{N}_{2}}$ & Nitrogen molar mass & $28 \times 10^{-3} \mathrm{~kg} \mathrm{~mol}^{-1}$ \\
\hline$M_{v}$ & Vapor molar mass & $18 \times 10^{-3} \mathrm{~kg} \mathrm{~mol}^{-1}$ \\
\hline $\mathrm{R}_{\mathrm{O}_{2}}$ & Oxygen gas constant & $259.8 \mathrm{~J} \mathrm{~kg}^{-1} \mathrm{~K}^{-1}$ \\
\hline $\mathrm{R}_{\mathrm{N}_{2}}$ & Nitrogen gas constant & $296.8 \mathrm{~J} \mathrm{~kg}^{-1} \mathrm{~K}^{-1}$ \\
\hline$R_{v}$ & Vapor gas constant & $461.5 \mathrm{~J} \mathrm{~kg}^{-1} \mathrm{~K}^{-1}$ \\
\hline $\mathrm{R}_{a}$ & Air gas constant & $286.9 \mathrm{~J} \mathrm{~kg}^{-1} \mathrm{~K}^{-1}$ \\
\hline $\mathrm{y}_{\mathrm{O}_{2}}$ & Molar fraction of oxygen in dry air & 0.21 \\
\hline$k_{\mathrm{ca}}$ & Orifice flow constant & $2.5 \times 10^{-3} \mathrm{~kg} \mathrm{~s}^{-1} \mathrm{kPa}^{-1}$ \\
\hline$n$ & Number of cells & 100 \\
\hline$F$ & Faraday constant & $96,485^{\circ} \mathrm{C}$ \\
\hline $\mathrm{P}_{\mathrm{ca}, \text { in }}$ & Pressure of inlet gas at the cathode & $150 \mathrm{kPa}$ \\
\hline$P_{r m}$ & Pressure of return manifold & $140 \mathrm{kPa}$ \\
\hline $\mathrm{V}_{c a}$ & Volume cathode & $0.01 \mathrm{~m}^{3}$ \\
\hline$\phi_{c a, i n}$ & Relative humidity of inlet gas at the cathode & $80 \%$ \\
\hline$k_{1}$ & Controller parameter & $1.3 \times 10^{3}$ \\
\hline
\end{tabular}

In this study, to achieve water management improvement, $y_{\text {ref }}$ is calculated based on the desired average membrane water content value $\lambda_{\text {ref, }}$ mbr using the following procedure. First, the average water activity $a_{m}$ is calculated based on [23]:

$36 a_{m}^{3}-39.85 a_{m}^{2}+17.81 a_{m}+0.043-\lambda_{\text {ref, } m b r}=0$

The average water activity $a_{m}$ is the real solution of the above equation. Indeed, since $\lambda_{\text {ref, }}$ mbr is a real positive number, it can be demonstrated that $\mathrm{Eq}$ (11) admits one real solution and a complex conjugate pair of solutions.

Cathode water activity $a_{c a}$ is then obtained from $a_{m}$ and the anode water activity $a_{a}=P_{v, a} / P_{\text {sat }}^{T_{a, i n}}$ :

$$
a_{c a}=2 a_{m}-a_{a}
$$

where $P_{v, a}$ and $T_{a, i n}$ denote the vapor partial pressure and the inlet gas temperature at the anode, respectively.

Eventually, the desired mass of water is obtained by:

$y_{\text {ref }}=\mathrm{V}_{\text {ca }} \mathrm{a}_{\text {ca }} P_{\text {sat }}^{T_{\text {cain }}} /\left(R_{\mathrm{v}} T_{\text {st }}\right)=f\left(\lambda_{\text {ref, }, \text { mbr }}\right)$

In the present work, the desired output $y_{\text {ref }}$ is calculated according to the desired average membrane water content. As a result, the membrane water content $\lambda_{m b r}$ is indirectly controlled by following a specific trajectory of mass of water.

Note that $m_{\mathrm{O}_{2}}, m_{\mathrm{N}_{2}}, m_{v, m b r}$ and their derivatives are not considered here as state variables, but as known disturbances.

The overall control scheme of the water management is clearly illustrated in Fig. 1.

\section{Simulation-based results}

In this section, the performance of the proposed control strategy is investigated in simulation environment. In this aim, a mechanistic model, presented and experimentally validated in Refs. [24], is used to simulate a $10 \mathrm{~kW}$ PEMFC (CEA LITEN Grenoble, France) presented in Ref. [25]. Both process simulator and flatness-based controller are implemented into the Matlab ${ }^{\circledR}$ environment.

Here, three scenarios are considered to exemplify the controller performance. The first scenario illustrates the tracking capability, whereas the second one evaluates the disturbances rejection ability. The third scenario is designed to assess the controller performance in terms of robustness
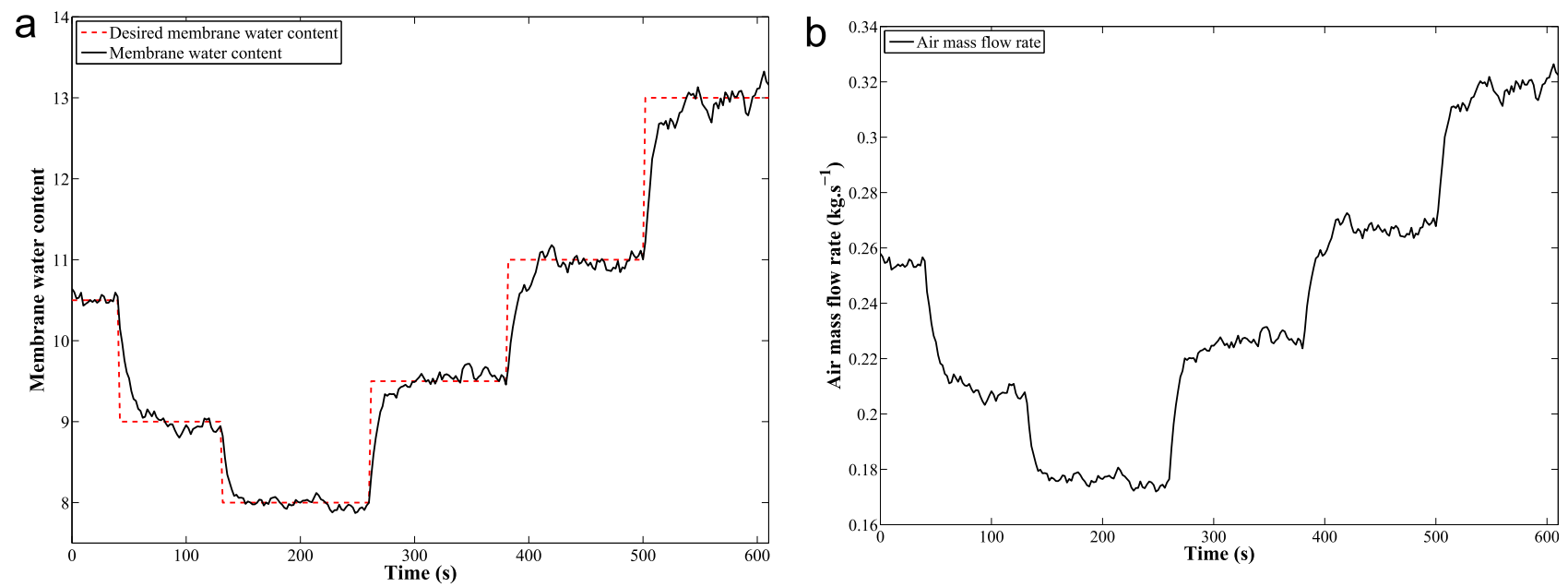

Fig. 2 - Tracking capability: (a) membrane water content; (b) air flow rate. 

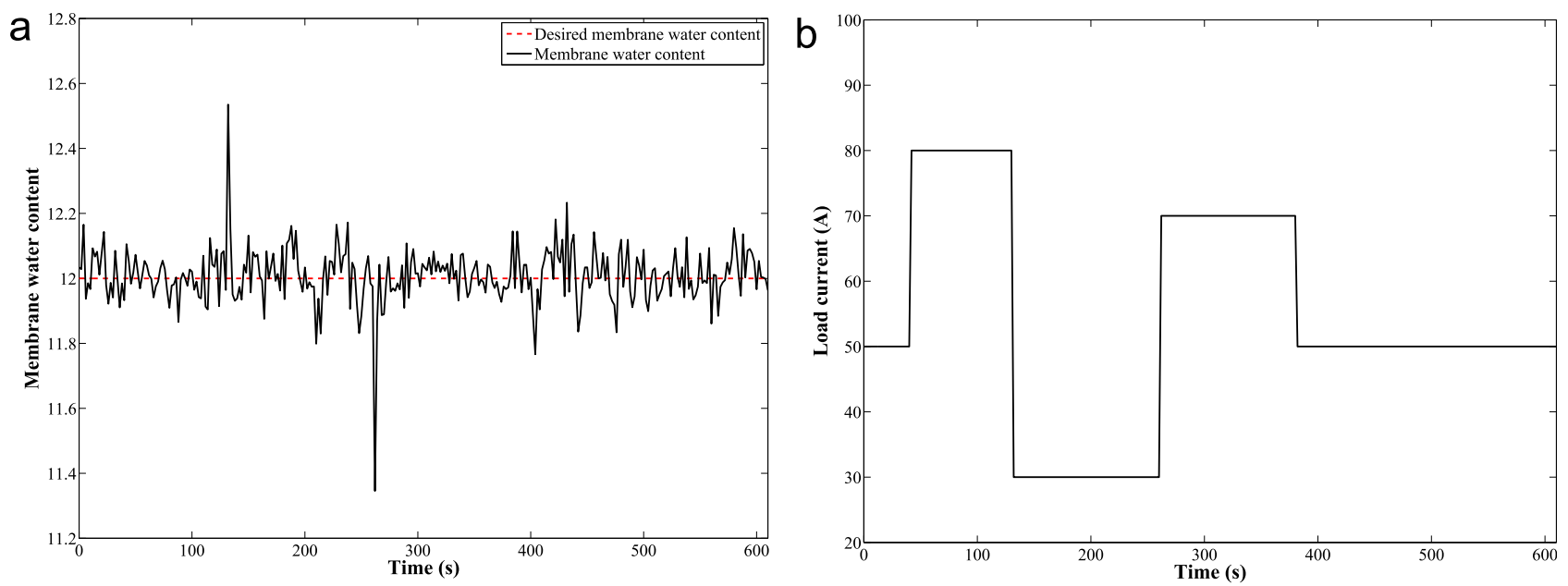

Fig. 3 - Disturbances rejection ability: (a) membrane water content; (b) measured disturbance.

against parameter uncertainties, which are unavoidable in realworld conditions. In the following, to be as close as possible to the experimental context, a white Gaussian noise with a signal to noise ratio of $30 \mathrm{~dB}$ is added to the outputs of the process simulator. It is obvious that to ensure optimal performance and safety operations, others variables such as stack temperature have to be regulated. It is thus assumed that all these variables are properly controlled. Flatness-based controller parameters are depicted in Table 1. In the sequel, the inlet air mass flow rate is the manipulated variable, the current is considered as a measured disturbance, and the sampling period is set to $1 \mathrm{~s}$.

\section{First case scenario}

As illustrated in Fig. 2, the controller tracks efficiently the desired membrane water content $\lambda_{\text {ref, } m b r}$, while offering an entirely suitable dynamic for the manipulated variable. Indeed, with a mean absolute error of 0.15 the controller demonstrates excellent tracking capability, which allows to manage efficiently the membrane water content $\lambda_{m b r}$. It can be pointed out that the inlet air mass flow rate computed by the flatness-based controller is affected by the noise. This is due to

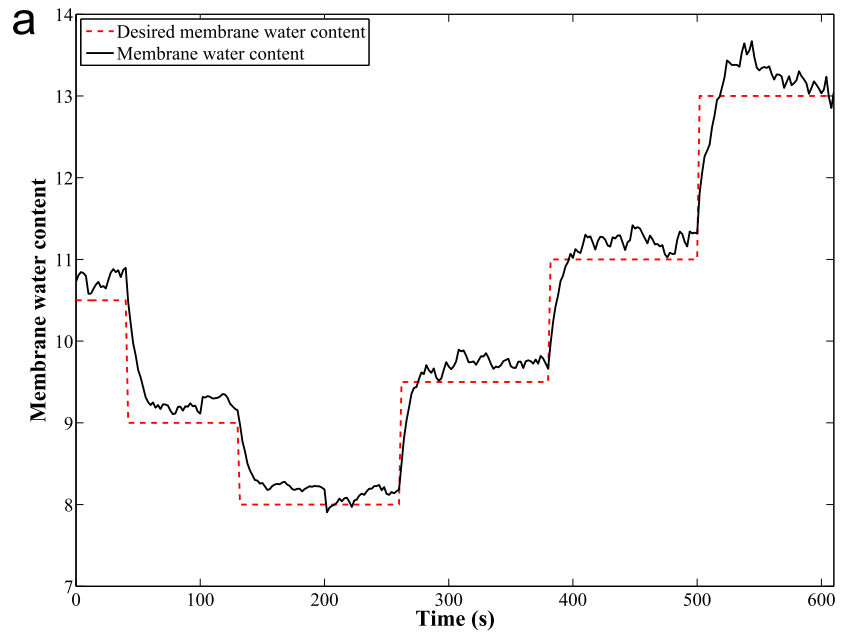

the fact that the control law is directly deduced from the model of the process. In practice, this limitation is easily overcome either filtering on-line the measurements or directly the control action.

Note that in this control scenario, the load current is set to $50 \mathrm{~A}$ and maintained constant.

\section{Second case scenario}

In this case, disturbances rejection ability of the controller is exemplified performing a set of step changes on the load current. To ensure that the flatness-based controller performs accurately regardless of the power level, load current steps are chosen to cover the whole operating conditions. The flatnessbased controller exhibits good disturbances rejection capability (Fig. 3). Indeed, set-point tracking errors induced by load current steps are swiftly compensated.

\section{Third case scenario}

To appraise the robustness of the controller against plantmodel mismatch, a modeling error is introduced between

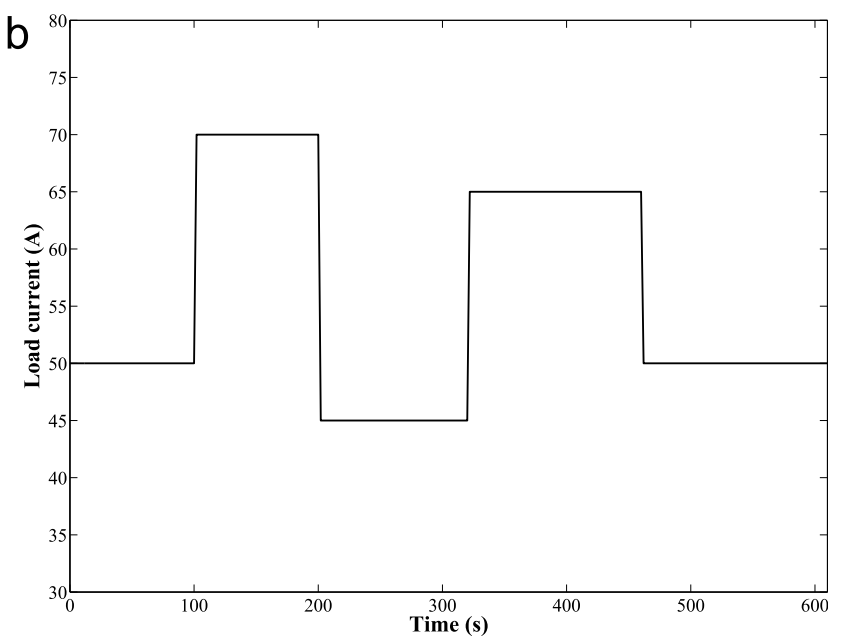

Fig. 4 - Controller performance in realistic conditions: (a) membrane water content; (b) measured disturbance. 
the simulator and the flatness-based controller. To this end, the orifice flow constant $\mathscr{K}_{c a}$ is increased by $20 \%$ in the control laws. The orifice constant used in the control law is taken to be $3 \times 10^{-3} \mathrm{~kg} \mathrm{~s}^{-1} \mathrm{kPa}^{-1}$, whereas the one used in the process simulator is set to be $2.5 \times 10^{-3} \mathrm{~kg} \mathrm{~s}^{-1} \mathrm{kPa}^{-1}$.

With a mean absolute error of 0.26 the proposed control strategy exhibits excellent robustness against parameter uncertainties, even in the presence of measurement noise. Indeed, the controller tracks efficiently the desired membrane water content, while compensating the process disturbances (Fig. 4). It can be noted that the modeling error involves a small steady-state error. In the present case, regarding the control objective, the accuracy remains entirely satisfactory. However, if required, this error can be further reduced by introducing an integral term in the closed-loop control law [26-28].

It is important to note that in addition to the presented examples, extensive simulation analysis has been conducted to assess the controller performance. In each case, highly satisfactory results have been obtained, in terms of tracking capability, disturbances rejection ability and robustness against parameter uncertainties and measurement noise.

\section{Conclusions}

In this study, a novel approach based on Differential Flatness Theory, has been proposed in views of improving PEMFC water management. This approach has been designed to ensure optimal PEMFC efficiency, while avoiding flooding or membrane drying. In this aim, a flatness-based controller has been developed to regulate the membrane humidity using the air mass flow rate as manipulated variable. The efficiency and the relevance of this strategy have been assessed in simulation environment through several control scenarios for a $10 \mathrm{~kW}$ PEMFC system. In each case, the proposed strategy demonstrated highly satisfactory results, since it successfully managed the PEMFC water content. Moreover, the controller exhibited excellent tracking capability, and disturbances rejection ability, even in presence of parameter uncertainties and measurement noise.

The proposed flatness-based approach appears to be a very promising strategy. Indeed, a proper membrane humidity regulation can not only improve the PEMFC efficiency, but may also extend its lifetime by preventing irreversible damages.

\section{RE F E RENCES}

[1] Jiao K, Lia X. Water transport in polymer electrolyte membrane fuel cells. Prog Energy Combust Sci 2011;37:221-91.

[2] Haddad A, Bouyekhf R, Moudni AE. Dynamic modeling and water management in proton exchange membrane fuel cell. Int J Hydrogen Energy 2008;33:6239-52.

[3] Zhang L, Pan M, Quan S. Model predictive control of water management in PEMFC. J Power Sources 2008;180:322-9.

[4] Hussaini IS, Wang CY. Dynamic water management of polymer electrolyte membrane fuel cells using intermittent RH control. J Power Sources 2010;195:3822-9.

[5] Sedighizadeh M, Fathian K. Dynamic modeling and adaptive control of voltage in proton exchange membrane fuel cell using water management. Int J Energy Res 2012;36:1201-14.
[6] Khoeiniha M, Zarabadipour H. Optimal control design for proton exchange membrane fuel cell via genetic algorithm. Int J Electrochem Sci 2012;7:6302-12.

[7] Villagra J, Novel BA, Mounier H, Pengov M. Flatness-based vehicle steering control strategy with SDRE feedback gains tuned via a sensitivity approach. IEEE Trans Control Syst Technol 2007;15:554-64.

[8] Morio V, Cazaurang F, Vernis P. Flatness-based hypersonic reentry guidance of a lifting-body vehicle. Control Eng Pract 2009;17:588-96.

[9] Aschemann H, Schindele D. Sliding-mode control of a highspeed linear axis driven by pneumatic muscle actuators. IEEE Trans Ind Electron 2008;55:3855-64.

[10] da Silva PSP, Rouchon P. Flatness-based control of a single qubit gate. IEEE Trans Autom Control 2008;53:775-9.

[11] Gensior A, Sira-Ramirez H, Rudolph J, Guldner H. On some nonlinear current controllers for three-phase boost rectifiers. IEEE Trans Ind Electron 2009;56:360-70.

[12] Danzer MA, Wilhelm J, Aschemann H, Hofer EP. Model-based control of cathode pressure and oxygen excess ratio of a PEM fuel cell system. J Power Sources 2008;176:515-22.

[13] Song E, Lynch AF, Dinavahi V. Experimental validation of nonlinear control for a voltage source converter. IEEE Trans Control Syst Technol 2009;17:1135-44.

[14] Agrawal SK, Pathak K, Franch J, Lampariello R, Hirzinger G. A differentially flat open-chain space robot with arbitrarily oriented joint axes and two momentum wheels at the base. IEEE Trans Autom Control 2009;54:2185-91.

[15] Rabbani T, Munier S, Dorchies D, Malaterre P, Bayen A, Litrico X. Flatness - based control of open-channel flow in an irrigation canal using SCADA. IEEE Control Syst Mag 2009;29:22-30.

[16] Guay M. On the linearizability of nonisothermal continuous stirred-tank reactors. Automatica 2002;38:269-78.

[17] da Fonseca R, Bideaux E, Gerard M, Jeanneret B, DesboisRenaudin M, Sari A. Control of PEMFC system air group using differential flatness approach: validation by a dynamic fuel cell system model. Appl Energy 2014;113:219-29.

[18] Thounthong P, Tricoli P, Davat B. Performance investigation of linear and nonlinear controls for a fuel cell/supercapacitor hybrid power plant. Electr Power Energy Syst 2014;54:454-64.

[19] Fliess M, Lévine J, Martin P, Rouchon P. Flatness and defect of nonlinear systems: introductory theory and examples. Int J Control 1995;61:1327-61.

[20] Lévine J. Analysis and control of nonlinear systems: a flatness-based approach. Springer; 2009.

[21] Fliess M, Lévine J, Martin P, Rouchon P. A lie-bäcklund approach to equivalence and flatness of nonlinear systems. IEEE Trans Automatic Control 1999;44:922-37.

[22] Sonntag RE, Borgnakke C, Wylen GJV. Fundamentals of thermodynamics. 5th ed. John Wiley \& Sons Inc; 1998.

[23] Springer TE, Zawodzinski TA, Gottesfeld S. Polymer electrolyte fuel cell model. J Electrochem Soc 1991;138:2334-42.

[24] del Real AJ, Arce A, Bordons C. Development and experimental validation of a PEM fuel cell dynamic model. J Power Sources 2007;173:310-24.

[25] Damour C, Benne M, Kadjo JJK, Rosini S, Grondin-Perez B. Fast NMPC scheme of a $10 \mathrm{~kW}$ commercial PEMFC. Int $\mathrm{J}$ Hydrogen Energy 2013;38:7407-13.

[26] Dunia R, Edgar T, Fernandez B. Effect of process uncertainties on generic model control: a geometric approach. Chem Eng Sci 1997;52:2205-22.

[27] Duvall M, Riggs BJ, Lee P. Multi-model decoupled generic model control. Control Eng Pract 2001;9:471-81.

[28] Madar J, Abonyi J, Szeifert F. Feedback linearizing control using hybrid neural networks identified by sensitivity approach. Eng Appl Artif Intell 2005;18:335-43. 